Article

\title{
EVALUATING AND CONSTRUCTING THE 'FRIEND' IN CRISIS. MEDIATED DEPICTIONS OF RUSSIA IN THE NEWSPAPERS OF CYPRUS
}

\author{
Kyriakos Kolovos ${ }^{\star}$ \\ Costas Venizelos ${ }^{\star *}$ \\ Emmanouil Takas ${ }^{\star * *}$ \\ Sofia Iordanidou ${ }^{\star * * *}$
}
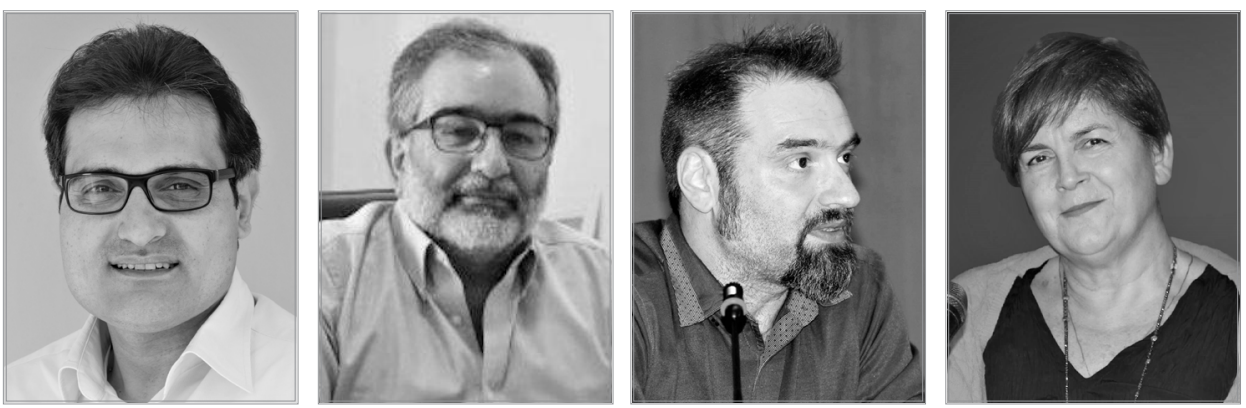

The main purpose of the present study is to explore and evaluate the diachronic relations between Russia and Cyprus, noting their historical context and to examine the perceived image 1 of Russia in the Cypriot press, during the crucial period of Eurogroup's decisions of March 2013.

In 1878 the UK rented Cyprus from the Ottoman Empire in exchange of a British promise to help Turkey against Russia. In 1914, the UK annexed the island and Cyprus became a British Colony because the Ottoman Empire entered the First World War on the side of the central powers. According to the Treaty of Lausanne (1923), the

\footnotetext{
* Kyriakos Kolovos, PhD Candidate at Open University of Cyprus, Researcher at Advanced Media Institute e-mail: kyriakos.kolovos1@st.ouc.ac.cy ORCID ID: 0000-0001-5890-1790
}

Costas Venizelos, PhD, Visiting Professor European University Cyprus e-mail: costas.venizelos@phileleftheros.com ORCID ID: 0000-0002-1799-6313

Emmanouil Takas, PhD, Advanced Media Institute, Open University of Cyprus, Senior Instructor of Political and Social Psychology e-mail: m.takas@cityu.gr; anostakas@gmail.com ORCID ID: 0000-0003-1334-5748

Sofia Iordanidou, Communication and New Journalism Associate Professor, Open University of Cyprus, Chair Advanced Media Institute

e-mail: sofia.iordanidou@ouc.ac.cy

ORCID ID: 0000-0002-8391-9164

\footnotetext{
1 The 'image', according to Boulding (1956) is a cognitive structure and is separated to 'image perceived' and to 'image projected'.
} 
Ottomans quitted all of their requirements on Cyprus-and the new status led the UK to declare the island as a Crown's colony in 1925 (Stavrinides 1975, p.2). This event coincided with the creation of the Communist Party of Cyprus (1926) as a blueprint for the global resonance that the Bolshevik movement gained, expressed in the October 1917 Revolution. These events resulted in cultivating within the working class of Cyprus, a communist ideology which, over time, founded the Cypriot Left. Apart from the ideological associations or the religious ones, on the basis of common doctrine, since 1960, after the founding of the Republic of Cyprus, these relations have become transnational in political and economic terms.

\section{Historical Context of Cyprus - Russia Relations}

$\mathrm{D}$ iplomatic relations between the Russian Federation and the Republic of Cyprus dated back to 1991, even before the Russian Federation was recognised as the successor of the Soviet Union in 1992. The Soviet Union, as a permanent member of the UN Security Council, was one of the first countries that recognised the Republic of Cyprus as an independent State 2 .

Historical and cultural ties connect $\mathrm{Cy}$ prus and Russia for hundreds of years. With the establishment of the Republic of Cyprus in 1960, diplomatic relations with the then USSR (18 August 1960) were immediately followed. The friendly nature of bilateral relations is reflected by the identification or proximity of the two countries' positions in major international problems as well as the consistent and valuable support of Russia in its efforts to achieve a just, viable and comprehensive solution to the $\mathrm{Cy}$ prus problem on the basis of relevant UN Security Council resolutions ${ }^{3}$.

Therefore, relations between the Russian Federation and the Republic of Cyprus have always been considered stable and positive ${ }^{4}$ with some exceptions ${ }^{5}$. The establishment of the Republic of Cyprus in the 1960s in the middle of the Cold War could not leave the course of Cyprus unaffected. The fact that the founding act of the newly established State was accompanied by the guarantee and invasive rights of three NATO member countries and the simultaneous strong resonance of the Left on the island made it a place of particular importance for the Soviet, as well as for Russian interests. The Cold War period and the role of Turkey in servicing NATO's interests, the agreements establishing the Republic of Cyprus in 1960, a State with many constitutional imbalances, led the newly established Cypriot State to closer relations with the Soviet Union, even though the country has been a member of the "Non-Aligned" since 1961.

Concerning the attitude of the Soviet Union on the Cyprus issue, before and after the Turkish invasion in 1974, there are two schools of thought in Cyprus. The one dictates that USSR has assisted the Republic of Cyprus during the Cold War: In recent decades, just as during the Cold War, the US and the UK, seeking to serve their power-political interests and by -favouring Turkey for the aforementioned reasons, were essentially antagonised by the Republic of Cy-

2 From the official website of the Russian Embassy in Cyprus: https://cyprus.mid.ru/en_GB/web/cyprus_en/relationsbetween-cyprus-and-russia

3 Consulate General of Cyprus in Krasnodar. (2019). Cyprus-Russia relations. [online] http://www.mfa.gov.cy/mfa/ consulate/consulate_krasnodar.nsf/krasnodar_consulate23_gr/krasnodar_consulate23_gr?OpenDocument [Accessed 01May 2019].

4 "The Sides confirm that the development of bilateral cooperation in the humanitarian field has a strong foundation with regard to historic, cultural and religious closeness of the peoples of the two States .Joint Declaration Mentvetef Christofia"at https://cyprus.mid.ru//web/cyprus_en/joint-declaration-on-further-intensification-of-the-relations-offriendship-and-comprehensive-cooperation-between-the-republic-of-cyprus-and-the-russian-federation [Accessed 01May 2019].

5 Mrs Zakharova, spokesperson of Russia's MFA, warned Cyprus for the US-Cyprus relations: "Russia has pointed out to the leadership of the Republic of Cyprus on numerous occasions that further efforts to militarise the island and draw it into US and NATO plans for the Eastern Mediterranean and Middle East regions would inevitably lead to dangerous destabilisation effects for Cyprus itself. Moscow cannot turn a blind eye to the anti-Russia nature of these plans and, should they materialise, will be forced to take retaliatory action." At http://www.mid.ru/en_GB/press_ service/spokesman/briefings//asset_publisher/D2wHaWMCU6Od/content/id/3430111 [Accessed 1 May 2019]. 
prus. On the other hand, Cyprus has been supported primarily by Moscow and Athens, and additionally by Paris and Beijing at the UN, and to some extent, albeit inconsistently, by the European Union (Melakopides 2016: 17). There is the view that the Soviet Union has exploited the instabilities that were created through Cyprus and the Cyprus problem to cause internal problems to NATO: It is well documented that the US tolerated the invasion not because it was the initiator and the its organiser believed in 1974 and the last Cypriot, but because Turkey flirted with the Soviet Union and was very important as an ally to ignore it. What has never known in Cyprus was that the Soviet Union propagated internationally in favour of the Turkish invasion (Drousiotis, 2011).

In 1964, when Turkey threatened to invade Cyprus, Nikita Khrushchev's intervention was considered as a catalyst in the final decision by the US and Lyndon Johnson to cancel the Turkish plans, something that was not repeated by the Soviet Union in 1974 when President Makarios asked for further assistance. As Venizelos and Ignatiou (2002, P. 295-96) note: "It is a fact that several times Soviets supported Makarios, but in critical moments they abandoned him as they did not want to outrage the US. The Soviets had decided to assist in United Nations issues, but to maintain an "independent" stance in Cyprus-UK bilateral relations". However, historic déjà vu, the current cooperation strategy between Turkey and Russia (see S-400) and the simultaneous inconvenience of the US appeared just after the Turkish invasion of the island.

The relations of the two countries, however, were constructed in multiple levels and expectations: The Soviet Union, initially, and Russia, subsequently, was the main source of military equipment for the Republic of Cyprus ${ }^{6}$ and was an export destination for Cypriot products. Cyprus, due to its geographical location, the tax environment for offshore companies was an ideal destination for Soviet Enterprises ${ }^{7}$.

These relations have been strengthened even further since 1990: (a) At the military level, the Republic of Cyprus was reinforced with a multitude of Russian tanks and anti-aircraft systems; (b) Cyprus continued to be an attractive destination of Russian funds and a service provider for Russian companies until 2013, and an evolving tourist destination for Russian travellers and, (c) with the accession of Cyprus to the European Union on 1 May 2004, added another dimension to relations between Cyprus and Russia ${ }^{8}$

\section{Cyprus and Economy}

Russia's contribution to two crucial phases of the Republic of Cyprus over the past 15 years has also been decisive: (a) Following the rejection of the Annan Plan, in the referendum of 24 April 2004, Russia vetoed a draft resolution constructed with the support of the US and the UK, blocking adoption of the resolution, which was also supported by all elective United Nations Security Council (UNSC) members, by exercising its veto power (Pericleous 2009: 301), in response to the request of the Republic of Cyprus. According to Lillikas, a former Minister of Foreign Affairs of the Republic of Cyprus, the effort of Turkey and its allies to create a framework of legitimacy for the development of the pseudo-state [TRNC] relations with the rest of the world was prevented by the help of our traditional friends [Russia and France] of permanent members of the Security Council" (Lillikas 2014, P. 162) as opposed to the Anglo-American policy-makers who have long been fixed on the alleged "bicommunal" character of the conflict (Melakopides 2016, P. 19).

In 2014, due to the annexation of Crimea by Russia, the EU decided to impose economic measures, which was extended to Russia by June 2019 with an impact on Cypriot financial transactions. In 2014 and 2015 there was a significant decline in the export of Cypriot products to Russia due to counter-measures taken by the Russian government. Despite the concerns expressed by Cyprus, it seemed that these relations had been restored taking into account that 2017 was the best year in the economic dealings

\footnotetext{
6 "The year 1997 did not start well. Within a few days of the beginning of the year it was announced that the Greek Cypriots had signed a contract with Russia to purchase S300 surface-to-air missiles."(Hannay 2005:70).

7 "Cyprus has become the preferred conduit for profits flowing from the Soviet Union to third countries. Offshore companies in Cyprus pay one-tenth of the standard income tax rate. Currently, they are taxed at the rate of $4.25 \%$. One way to qualify for this preferential rate is for the company to incorporate in Cyprus. The Cypriot corporation must be owned exclusively by non-residents of Cyprus, and it must conduct its business and derive its income from activities outside of Cyprus. One offshore company may hold shares in another without compromising the tax privileges of either."(Ruth 1989, p.132-133).

8 Consulate General of Cyprus in Krasnodar . (2019). Cyprus-Russia relations. [online] http://www.mfa.gov.cy/mfa/ consulate/consulate_krasnodar.nsf/krasnodar_consulate23_gr/krasnodar_consulate23_gr?OpenDocument [Accessed 01May 2019].
} 
of the two countries, as shown by imports of Russian products in Cyprus, the island's exports to Russia while arrivals of Russian tourists recorded a record of all ages.

When the Crimean crisis erupted, Cyprus' political class and most opinion-makers favoured Moscow's position and argumentation (Melakopides 2016, P. 76). The Russian Federation had already proceeded with the granting of a EUR2,5 billion loan to the Republic of Cyprus, at the end of 2011, in order for the island to satisfy its financing needs. The fact that a large volume of deposits with Cypriot banks before 2013 came from Russian capital, as well as the general provision of services by accountants, lawyers or other agencies, created relationships of dependence between the Cyprus economy and the Russian interests.

Numerous articles from western media, (Wall Street Journal 2013; Der Spiegel 2012) targeted mainly against the Russian interests, resulted in an attitude that affected the decisionmaking processes regarding the economy of Cyprus in the Eurogroup of 2013.

Amidst a widely held perception that the European allies had betrayed Cyprus, President Anastasiades tried unsuccessfully to seek some sort of financial aid from Russia returning finally to the troika (Katsourides, 2013 P. 53). The closure of the banks and the subsequent "haircut" of deposits influenced the international economic system by affecting foreign investors, mainly Russian (Iordanidou \& Samaras, 2014. P. 74-75).

In this context, it is crucial to explore the ways in which the Cypriot media constructed the image of Russia through the aforementioned period. This paper explored the ways in which the Cypriot media "frames" the relationship between a financially dependent country (Cyprus) and a country struggling to enlarge and strengthen its sphere of influence in the Mediterranean (Russia).

\section{Framing Theory}

The analysis of media in the context of framing reveals the organisation of the participants' experience in a communicative act, determined by the particularities of the time when this communicative act is realised and simultaneously influenced by the sociopsychological conditions which place the particular "scene" of this communicative act (Kihlstrom, 1987). Thus, the hermeneutical choices of the content are dictated, evaluated and interpreted not only by the immediate context, but also by the wider environment in which the discourse unfolds and is recorded. Thus, verbal choices do not have inher- ent meaning but become meaningful when they are perceived within a context, or a story, which organises and gives them consistency, choosing and projecting specifiy facts and ignoring others (Gamson, 1989. P. 157). In addition, the meaning of these lectical choices acquires a different content depending on the perception of the sender of any message. Therefore, meaning is not articulated in an ideological gap, but the way in which it is produced, evaluated, understood and interpreted, can be considered as a function of the interpretative procedure (van Dijk, 2005). The basic practical implication of a frame is the formation of a series of social norms which ensure a common understanding by a particular group, reflect the perceived "legitimate" social purposes (Ruggie, 1998) and create collective expectations (Jepperson et al., 1996).

In 1955 anthropologist Gregory Bateson (1972. P. 187) introduced the term "frame" to describe the context in which an interaction takes place. Within the context of the matter, the senders send meta-messages, which define the boundaries of communication and determine whether this interaction will be serious, playful, ironic, or aggressive. Bateson arrived at a conclusion, observing the game of apes, where one often was biting the other. However, in this context, the bite was coded as a "time to play" message rather than as a threat. The "play" message in this context the frame of the action, can be reworded as "the actions we are now involved in do not imply this, which they would indicate" by removing the threat and directing the recipient to the "game".

Goffman (1974. P. 21) considers that when a person recognises a particular event tends to trigger one or more contexts called "frameworks" or "schemata of interpretation" in his reaction to the event, which they are exposed to, and which they use, without necessarily knowing their existence or their manifestations. Social frameworks, for example, work unconsciously, but they carry valuable information encoding the person's environment while defining it (Goffman, 1974). Therefore, they help him construct an aspect of reality and interpret it by defining his conscious or unconscious understanding of social activities. However, the complexity of human communication and its various expressions could not be interpreted exclusively through a specific context. For this reason, Goffman (1974. P. 25) defines a "primary framework", the frame that is initially triggered, entangling and possibly defining the sequence of the remaining frames. In this way the framing process is systematically approached. The interdisciplinary nature of the term, however, 
is an obstacle to its clear identification in the field of communication. Goffman's sociological approach has been applied to identity theories (Coy \& Woehrle, 2010), immigration (Dove, 2010), religion (Yao, 2007) and social studies (Franceschet, 2004) where the interpretation of central terms of sociology was investigated.

According to Entman (1993, P. 52) framing is the process of selection of, "some aspects of a perceived reality and make them more salient in a communicating text in such a way as to promote a particular problem definition, causal interpretation, moral evaluation and/or treatment recommendation," influencing viewer's interpretations, evaluations and judgments (Price \& Tewksbury, 2000. P. 57). The 'angle' or 'storyline' that transforms an occurrence into a news event, and then into a news report is defined as 'frame'; a procedure which is inherent in the news-making process, since media cannot offer a mirror reflection of reality but involves selection (Takas and Samaras, 2016. P. 3). As Cappella and Jamieson (1997, P. 39) argue, "those rhetorical and stylistic choices, reliably identified in news, alter the interpretations of the topic treated and are a consistent part of the news environment". "Frames in the news can be examined and identified by "the presence or absence of certain keywords, stock phrases, stereotyped images, sources of information and sentences that provide thematically reinforcing clusters of facts or judgments" (Entman, 1993. P. 52).

According to Price et al. (1995) any news event can be categoriwed according to one of the following frames: (a) conflict frame that organise the story in terms of the conflict between opposing interest groups. (b) human interest frame that organises the story by focusing on the victims or (c) consequence frame where the story is organised in terms of its consequence for some group. Interpretation frames link events, issues and news agenda with nations' image (Samaras and Iordanidou, 2014. P. 236). Common frames such as "human impact," "powerlessness," "economics," "moral values," and "conflict" are used by the media and the audience (Neuman et al., 1992). Following their categorisation the frames are distinguished by: (a) the "powerlessness" which has to do with "the dominance of forces over weak individuals or groups" (ibid, P. 67). (b) the "economics frame" reflected the concerns about "profit and loss" (ibid, P. 63). (c) the "moral values frame" referred to morality and social prescriptions including quotations or inferences. (d) the "conflict frame" refers to the journalistic practice of reporting stories of clashing interpretation and it was found to fit well with news media's "game interpretation of the political world as an ongoing series of contests, each with a new set of winners and losers" (Ibid p.64, cited by Semetko \& de Vreese, 2004. P. 94). The content of such an article is organised by contradictions, controversies, conflicts highlighting the image of a country involved in a confrontation (Samaras \& Iordanidou, 2014. P. 237).

Samaras and Iordanidou (2014, P. 237-238) introduced new frames relied on interpretation of the frame theory which have been used in the present study. (a) Frame of strategy. The country is presented according to its intensions and interests. The frame is also triggered when the country emerges during an antagonism. (b) Problematic Frame. The foreign country is presented by the press having problems which start from its own problematic status. (c) Frame of negative effect. The country is presented in terms of price or negative effects excluding the cases where the country is the source of these problems. (d) Frame of positivity. The country is presented in terms of positive outcomes rely on its own actions. (e) Fear/threat frame. The country is presented in terms of fear, threat and negative prospects for the future. (f) Frame of hope. The foreign country is presented in terms of hope and positive expectations that it experiences or creates. (g) Frame of dominant/hegemony. The country appears to dominate, control, apply power internationally, having comparative advantage or significance in a particular field.

Contemporary studies on frames have explored how framing may influence the ways in which individuals will ultimately take that decision. The influence of frames is defined as "the finding that decision-makers react differently to different but objectively equal descriptions of the question itself" (Kuehberger, 1998. P. 150). Price and Tewksbury (1997) focused on the effects of frames on three psychological mechanisms, availability, accessibility and applicability. An available interpretive schema is inherent in the individual cognition and is based on long-term memory. At the same time, an interpretative schema is applicable, that is, it is valid when new information completes it and thereby activates it. When a frame is enabled it remains in the working memory and is more likely to be used again in the near future. The concept of activation thus plays a prominent role in the accessibility of the interpretative schema and thus influences the interpretation of a phenomenon. Thus, different activation and accessibility processes constitute different conceptions, a dynamic process that is involved in the formation of social representations.

However, the effect of the interpretative schemata as they are formed does not seem to 
have the same effect, as between the construction of the frame and its effect lies the concept of mediators, which strengthens or weakens the influence of the frame (Chong \& Druckman, 2007). Mediators are based on both individuallevel moderators and contextual moderators. In one of the first studies of the influence of mediators, Miller and Fagley (1997) have shown that the influence of frames depends on variables such as rationality and probability of success in view of a risk selection. Additionally, Lecheler, deVreese \& Slothus (2009) argued that one of the key mediators is the significance of the issue for the individual, which is different for each and depends on his or her individual beliefs. This is borne out by the research by Bizer \& Krosnick, (2001), where importance seems to play a key role in the accessibility of information. The more important the information is in which an individual beliefs, the more easily it is revoked. In addition, the more important an issue is for the individual, the more information he/she is expected to have collected on the specific issue he will use to develop his own argument (Lecheler, deVreese \& Slothus, 2009), thus producing competitive interpretative schemata.

Futhermore, an important factor regarding the impact of a framework is the competitive context. The overflow of information and opposing views may lead to more confusion than to clarification, thus disordering the citizen and creating a sense of conflict. The frameworks help resolve this conflict by providing views on which the issues or views are relevant and important and which should be of less importance (Sniderman \& Theriault, 2004; Boeynaems, Burgers, Konijn \& Steen, 2017). Therefore, there is rarely a single framework, and many different alternative and often conflicting frameworks, and an issue can be re-framed either to support or to deconstruct the original frame. In the context of this particular research, the interpretative schemata used by the newspapers to frame Russia, can reveal the historical ties between the two countries as well as the frames that are historically recalled to shape and evaluate a new context between the two countries.

\section{Methodology}

For the purposes of this study, March 2013, a crucial period for Cyprus, in which Russia was directly involved, was selected. With the historical context of the two countries' relations as outlined above, a qualitative analysis of the con- tent of the three Cypriot newspapers, from 8-23 March 2013, attempted to ascertain whether the decisions taken at the Eurogroup level and the refusal of Russia, eventually, to participate in the memorandum had a drastic change in the way Russia is portrayed by the Cypriot press. Could - March 2013, mark changes in Russia's attitude towards Cyprus', tourism, energy topics and other issues of common interest, according to what is being protested in the Cypriot press?

Samaras (2014. P. 17), reviewing the bibliography on Theory of Image in International Relations, states that the concept of image in international relations is used to study the ways in which actors shape views, perceptions and policies for the international environment, and especially for other actors with whom they indirectly or immediately intertwine contributing to the analysis of the images of the other States, presented by interested State actors. Thus, the press as part of the communication system of a country in a relationship of interdependence with the domestic political system is the place and the means of imaging and promoting the image of a foreign State in the inner audience.

Content analysis is a research technique for making replicable and valid inferences from texts (or other meaningful matter) to the contexts of their use (Krippendorff, 2004. P. 18). Qualitative research "examines the qualities of communication phenomena whereby tends to be continuous rather than discrete, and emphasis is on description and explanation more than on measurement and prediction" (Fitch, 1994. P. 32).

The content of three newspapers was studied one week before and one week after the Eurogroup's decisions where the rescue of a bank using the same means (Bail-in) was first imposed. The newspaper "Phileleftheros" was characterised by Vrettos and Papagiannidis (2013/2016: 84) as a moderate and perhaps the most important newspaper in the modern history of the island. It is the first in circulation in Cyprus, moving more towards the centre. The newspaper Haravgi is the expressing body of the central committee of AKEL and the newspaper "Alithia" is traditionally on the right 9 . In this way, the whole ideological and political spectrum of the press was covered to ensure the validity of the research.

The main questions guiding this particular research are the following:

${ }_{9}^{9}$ For o complete list of Cyprus' Mass Media see at https://urlzs.com/tzCD [Accessed 01 May 2019] 
1. How did the aforementioned newspapers frame Russia in March 2013?

2. Has there been any differentiation in Russia's image following the Eurogroup's decisions regarding the historical context of Cyprus Russia relations?

\section{Results \\ Positive messages and the "Hope" frame}

Prior to Eurogroup decisions, Russia was characterised as a key for the conclusion of the Cypriot memorandum, as beyond the financial strand the loan agreement also brought a purely political stance. According to Karydes the issue was purely political, rather than economical, and the same time the Cypriot government was seeking the necessary political support from Russia who had a key role in the evolution of the discussions on the memorandum (Alitheia, 8.3.2013. P. 5) something that was also recognised by the editors of Phileleftheros ${ }^{10}$.

By defining the issue as purely political and not economical, it is to be understood that the accusations that weigh Cyprus as a "black" money laundering area, referring indirectly to the statements of Europeans on Russian deposits, were embarrassing the attitude of centres in Europe that see Cyprus as the scope for resolving political differences with Moscow rather than tackling the problem as solely economic. In addition, Russia was seen as the country which can make a positive contribution to the memorandum case:

"The issue is expected to be discussed at a meeting of President Anastasiades with President Putin in Moscow in the coming weeks, while Cyprus is seeking a 4,5\% interest rate cut to 2,5\%" (Phileleftheros, 9.3.2013. P. 2).

In contrast to Russia, the IMF and Germany appear as blackmailers:

"The IMF's insistence on reducing the Cypriot public debt to $95-100 \%$ of GDP in 2020 leads to the emergence of extreme scenarios that have been avoided even in the case of Greece, where international lenders have provided the country with a debt reduction margin of $122 \%$ in 2020" (Phileleftheros, 10.3.2013. P. 4).

The frame of hope was stepped up as the Eurogroup meeting approached regarding Russia's mediating, salvific, role.

"Officials also said that Cyprus has received strong indications from Russia, which has strong business ties with Nicosia that Moscow, could con- tribute to the rescue if it receives the same credit status as the Eurozone creditors, which means repay immediately after the IMF". (Phileleftheros, 9.3.2013. P. 36).

Many hopes were also invested in the visit of the Cypriot Finance Minister to Moscow, for a comprehensive agreement on Russia's participation in the memorandum. According to the newspaper Haravgi "[T]he Minister of Finance Michalis Sarris will be in Moscow next Monday to meet and discuss with his Russian counterpart Anton Gk. Siljanov, the ways in which Russia could help Cyprus overcome the economic difficulties it faces" (Haravgi, 14.3.2013. P. 15).

It is clear that prior to the Eurogroup decisions, reports in the Cypriot press had given up hope that Russia would contribute to the $\mathrm{Cy}$ prus financial problem. The historical relations between the two countries and the loan granted to Cyprus in 2011 presented Russia as the bridge that would save the Cypriot economy. At the same time, accusing the IMF and Germany of being blackmailers, putting them it in the negative frame, upgraded Russia's image as a friendly country became more obvious, according to the next paragraph which exams the differentiation on the dichotomy of "Us" and the "Others".

\section{Framing "Us" and the "Others"}

Reports and information on haircuts had worsened the depositors' psychology, making banks even more vulnerable. Appeals to avoid such statements were continuous in an attempt to frame Cyprus either in conjunction with Russia or alone as a victim. According to Professor Michaelides "[T]he statements about the haircut of unsecured deposits are dangerous to financial stability (and not only for Cyprus). They should be avoided by everyone. But not only Russia is being pressed in this way, but also Cyprus" (Phileleftheros, 9.3.2013. P. 36).

Framing has important implications for political communication playing a major role in the exertion of political power; the frame in a news text is really the imprint of power by registering the identity of actors or interests that competed to dominate the text (Entman, 1993. P. 53).

The Cypriot press in this context saw any assistance from Moscow as "help" opposed to the Troika loan, framing ' $U s$ ', the in-group, with the participation of Russia against the 'Others', IMF and Germany, the out-group. Following the strategic frame and the hegemony frame as

\footnotetext{
10 "Blackmailing dilemmas of IMF and German axis. Key for the Cypriot Memorandum is Moscow's participation" (Phileleftheros, 10.3.2013, Front Page).
} 
well, Russia is presented as the strategic ally who defined the situations as creating the 'necessity' of its involvement in Cyprus' rescue plan: 'The Russian Federation for its own strategic reasons and for political and economic interests has important interests and serves to save Cyprus. It has interests not to bankrupt the Republic of Cyprus [...] This road will bring benefits to both countries. Possibly as much more in Russia, but for Cyprus such a formula will be very important [...] We believe that Russia can be the way out for Cyprus " (Phileleftheros, 13.3.2013. P. 6) unlike the German Members who "did not fail to transfer to Cypriot MPs their annoyance about connecting Cyprus with Russia and the Russians" (Phileleftheros, 13.3.2012, p. 10) as the German political parties "have the impression that Cyprus is a tax paradise where risky money laundering is being carried out, mainly by the Russian oligarchs" (Phileleftheros, 13.3.2013. P. 10).

Theodoulou, a columnist of "Alithia", moving a step forward and referring to the historical ties between Cyprus and Russia noted: "“With regard to the Russian investments in our country, some have to understand that with Russia, Hellenism has relations for centuries. Among other things, it is the same Orthodox religion and the common struggles against the Ottoman Empire. The Russians and the other Orthodox find here an intimate, welcoming environment and a small, beautiful country that they can enjoy" (Alithia, 12.3.2013. P. 50). He entitled his article "The foreigners and us" making the distinction between identity and otherness: The Orthodox, Greeks and Russians, framing positively, are identified, while the Europeans, the Anglo-Saxons, the Ottomans are on the opposite side.

In general, the economic ties between the two parts were framed positively by all the spectrum of the press ${ }^{11}$. The exception was an isolated statement of the Minister of Tourism who used the problem frame for Russia stating that, 'despite the fact that 2013 would be better in terms of arrivals Russian tourists, compared to 2012, Cyprus should gradually be detached from Russian market ${ }^{12}$ preparing the next stage; the post-Eurogpoup's decisions period.'

\section{The Problem Frame. Fear after the Eurogroup Decisions}

The problem frame reproduces itself, in a sense of reframing; an ecology of communication which has contributed to the construction and routine use of a problem frame and expansion of fear in public discourse (Altheide, 1997. P. 665).

The decisions of Eurogroup were considered hostile by the Russian political leadership. The Russian president's frustration was evident as he described the "haircut" as "unfair, unprofessional and dangerous", while Prime Minister Medvedev warned by a change in Moscow's relations with Nicosia ${ }^{13}$, stating that Russia would be forced to introduce "corrections" in its relations with Cyprus (Phileleftheros, 17.3.2013. P. 2).

The statements made by Russian politicians had created a feeling of insecurity in Nicosia where developments could have affected Russia's stable positions on other issues such as the Cyprus' one. Venizelos, columnist of Phileleftheros, noted the serious risks: "EU and Cyprus shootings by Putin-Medvedev for the decision [...]. Would the haircut cut post on the Cyprus issue? Moscow has, over time, been a key supporter of Cyprus on the Cyprus issue and has given many defensive battles to the Security Council. He vetoed third-party approaches to the Cyprus problem and plays an important role in drafting resolutions on our national issue. Will this posture change after the latest developments? This will be thereafter"14. Identifying the Russian positions was expressed by the editorial director of the newspaper, highlighting the dangers for Cyprus because of the blow to the Russian interests:

"The statement of the Russian Prime Minister, $\mathrm{Mr}$ Medvedev, is a clear message that we must not ignore. If Russia decides to "correct" its relations with Cyprus, as Mr Medvedev warned, then Cyprus

\footnotetext{
${ }^{11}$ According to Haravgi $(13.3 .2013$, p.38) it seemed that Cyprus had largely regained the confidence of Russian investors and buyers, as well as the preference of tourists who seemed to flood summer clubs that summer too with the forecasts of raising 120,000 Russian tourists. For this development, the Christofias government contributed "in cooperation with the Russian government, with the implementation of electronic visa, gave a huge boost to the arrival of Russian tourists (Phileleftheros, 10.3.2013, p.28) and is now the donator of tourism in the free area of Famagusta. However, tourism is part of a wider strategic planning, since "the declaration of strengthening CyprusRussia relations and the prospect of a pragmatic, realistic policy towards Moscow was the stamp of the new foreign policy (Phileleftheros, 17.3.2013, p.9)

${ }^{12}$ Agathokleous, T. (2013, March 13). Straight forward for casino the next two years. Alitheia, p.8

${ }_{13}$ Zachariou, C. (2013, March 19). Anger in Russia for the 'haircut'. Haravgi, p.3

${ }^{14}$ Venizelos, C. (2013, March 19). S-300 range spikes. Russian irritation with Nicosia, as well, for the haircut of deposits. Phileleftheros, p.3
} 
will not lose only the vital Russian deposits and companies, it will lose even the most important ally in the economy, but also on the Cyprus issue. I do not know how to answer the Russian Prime Minister when he states that 'haircut' is a 'foreign money confiscation'. Why this is the truth. Confiscation or grabbing or appropriating foreign money" (Phileleftheros, 19.3.2013. P.3).

The same frame is recorded in the newspaper regarding the position that Cyprus is the "guinea pig" of the measures imposed and should not risk its relations with Russia:

"The helping hand was not for rescue but for the burial of the economy. Cyprus, due to its size, is used as a test animal. They try recipes to strengthen the strong and level the weak, the small [...] it is necessary to maintain our relations with Moscow. Not only in relation to the question of 'haircut' of deposits, which affects Russian citizens. But wider to maintain and strengthen the two countries' relations. We should not forget Russia's role in the Cyprus issue" (Phileleftheros, 10.3.2013. P. 4).

Similar, but with stronger oppositional positions, were recorded by the newspaper Haravgi, stating that the decisions of Eurogroup besides the danger of risking the relations with Russia, poses the question of government tolerance, which can also succumb to other demands of "foreigners" [Europeans and Americans], such as the Cyprus issue and natural gas:

"The result of the decision by the government to accept the Troika's extortion and pressure is that it has jeopardised our relations with a timeless strategic ally of Cyprus. Cyprus's relations with Russia are in danger of being cured due to the retreat of the Anastasiades government to accept the extortion and pressure of Europeans. Anastasiades showed an attitude of retreat to all foreign demands. Of course, they have not only plans for the economy, but also for the Cyprus issue and for gas. If tomorrow they come with a fixed solution - which of course will serve their own interests - who can guarantee that the government will not show the same reluctance? Who can guarantee that he will not give in to the pressures of foreigners on gas?" (Haravgi, 19.3.2013. P. 5).

On the opposite side of the above positions was the pro-government newspaper Alithia, which considered that relations between $\mathrm{Cy}$ prus and Russia were broken, without showing anything positive on the horizon: "Nothing changed. Despite the high expectations created by previous statements by Russian officials, Moscow's official stance on Nicosia's appeals is similar to what we have known in recent months. In a nutshell ... we are again waiting for the three main demands of Nicosia" (Alithia, 21.3.2013. P. 8).

Hatzidimitriou, an author of the newspaper, characterised the waiting for help from Russia as = "empty hopes" interpreting the phenomenon in terms of victimisation:

"People who are individually or collectively in a difficult situation can easily fall victim to erroneous or even falsified propaganda, that give them hope they need. In this case, with the difficulties we find ourselves as Cyprus at the edge of economic disaster, we wanted to believe that Russia would save us ... Despite the controversy, the whispering around this subject continues" (Alithia, 21.03.2013. P. 9).

The newspaper's attitude is made clearer through the editorial:

"MPs also felt that Russia would help and save Cyprus. An even more naive approach that was also proven the following day. And so the haircut remained an alternative plan to be drafted by the government" (Alithia, 21.03.2013. P. 10).

The pro-government press was trying to demystify the story that Russia will save Cyprus, as it said, "The help of the" blonde genus"15 was launched last summer by the Christofias government"16.

The above reports, from the newspaper Alithia, aimed at the deconstruction of what was cultivated in the previous period about Russia's contribution to the Cyprus agreement. Unlike the other two newspapers, focusing on the critical aspect and sensitivity of bilateral relations, at the risk of Cyprus losing a significant influence in its international relations, the pro-government newspaper mentions "empty hopes", in short illusions and delusions.

Fear is a mechanism that can be easily observed in attacks of anxiety panic in individuals (From 2001, P. 80). Fear and anger activate sharply contrasting perceptions of risk because perceptions of risk underlie countless decisions in daily life, ranging from relationships to finance to health; these contrasting perceptions may have manifold effects (Lerner \& Keltner, 2001. P. 155).

The fear that Cyprus was experiencing had two sources: Russia's own reaction and the risk of the Troika memorandum. This fear had been reframed, to a certain extent, by the centre-left newspapers with the desire to continue and strengthen Cyprus-Russia relations after the Eurogroup's decisions, while the indirect acceptance of the pro-government, right-wing newspaper to break those ties leading to a risk choice

\footnotetext{
${ }^{15}$ A ironical reference, since some "prophesies" foresee that Hellenism will be saved from the blond genus of the North ${ }^{16}$ Adeilinis, L. (2013, March 23). Cyprus ... Odyssey in Moscow. Alitheia, p. 7
} 
of a purely western memorandum. This is most evident by the framing of the bilateral cooperation in the post-Eurogroup era.

\section{Framing the Alliance}

Although Russia did not contribute to the programme of support for the Cypriot economy and although the Russian political leadership strongly opposed the decisions, even against Cyprus, part of the Cypriot press stressed the necessity of continuing the cooperation of the two parties.

'The Russian Federation is our mainstay. Not only in the field of economic cooperation but also in the political field [...] Mainly in the field of the UN Security Council in relation to the Cyprus Issue, but also in the economy of investment. The Cyprus problem is a bottleneck and always in Nicosia they know where to approach when a problem arises. We reiterate that Russian aid is welcome, we seek and invest in it and we need it. And can Cyprus offer the geopolitical advantages, geographic position to enhance its co-operation with the Russian Federation. No one should forget that there is now scope for cooperation on energy issues as well' (Phileleftheros, 20.3.2013, P. 6).

Contrary to the pro-governmental "Alitheia", the left-wing newspaper "Haravgi" assigned all responsibilities to President Anastasiadis, relieving Russia of any accountability. And in this case, the divisions of the past that wanted the Cypriot left to be identified with positions of the Soviet Union, rather than with the positions of the Cypriot right on issues of Cypriot interest. These appear with the official position of the newspaper that also reflects the position of AKEL since, according to the newspaper, the Cypriot government "turned its back in Moscow" as the President of the Republic, Mr. Anastasiades, in an unprecedented move in the political history, did not respond to an open invitation addressed to him by the President Vladimir Putin, despite the fact that Moscow, as indicated by the announcement of the Russian presidency, would be available to offer assistance to Cyprus. This is also highlighted by the editor of the newspaper:

"DISY and the President do not accept talks for a solution outside the EU structures and IMF, regardless of whether the entire people, especially the workers of this place, are sacrificed ... Because not only did he not visit the Russian capital, but they also closed the door to any service of Russian interests, thus irritating the Kremlin". (Haravgi, 23.3.2013, P. 6) Phileleftheros, moving in a more moderate context, left the possibility open for co-operation with Cyprus in the field of rescue, although Barroso attempted to prevent Moscow from participating in the Cypriot memorandum, ${ }_{1}^{17}$ despite the intense discomfort of Russian big energy companies with the Cypriot government which preferred to serve in the second round of exclusive economic zone (EEZ) licenses the positions and wishes of French Total and not those of Russian Novatec-Gazprombank ${ }^{18}$.

\section{Conclusion}

The aim of this study was to explore the mediated depictions of Russia in the Cypriot press. Qualitative analysis of the content of the three aforementioned Cypriot newspapers' articles was employed, using the framing theory as an analytical tool, we reached the following conclusions, while answering the research questions previously posed.

March 2013 tested the traditional CyprusRussia relations. Even though in the past, Russia was considered a strong and faithful ally to the Cyprus Republic, the political turmoil in March 2013 seems to have added political pressure to the representation of Russia as an ally. Russia's economic and geopolitical interests on the island were affected by the decisions of the Eurogroup thus resulting in a shift in the Russian interests and the re-negotiation of the former undisputable ally in the Cypriot press

Prior to the decisions of Eurogroup, the Cypriot press, as an expression of the local economic and political elite, was also presenting Russia as a key factor in the conclusion of the Cyprus memorandum and a source of hope for Cyprus. Russia's image was positively signified as a country that reinforced this frame and could function as an alternative political and economic force. The results from this particular study show that in the days following the Eurogroup's decisions, the Cypriot press was divided. The political pressure had steamed off into two contradictory and ideologically different directions.

The centre-left newspapers, in the face of a fearsome Troika memorandum, were urging the need to strengthen traditional bilateral relations. In the newspapers selected, the emergence of the "hope frame", namely the hope that the bi-

\footnotetext{
${ }_{17}$ Venizelos, C. (2013, March 22). Moscow left an open window. Fileleftheros, p. 5

18 Theocharides, P. (2013, March 22). Late interest. Fileleftheros, p.20
} 
lateral relations would not be affected, and the "fear frame", namely that Cyprus was a "guinea pig" of a European experiment that was aiming to hurt the Russian economy thus producing fear of instability in Cyprus, constructed the argument that Cyprus should by all means preserve the good relations with Russia. The "us and others" frame depicted the European decisions as "punishment" therefore placing Europe on the "out group" the "others", urging the Cypriot government to align to the Russian initiatives. The historical ties" was mainly employed to evoke the common ground of history and the need to further strengthen the relationship with Russia.

The right-wing, pro-government newspaper distanced itself from this perspective, and viewed the Troika risk as the only solution The "us and them" frame has a different content regarding the centre-left newspapers, namely the frame used offers interpretation of "us" by aligning the Cypriot interests with Europe. Cyprus belongs to the EU, and therefore the country should strengthen the ties with Europe. Russia, as the "other" is constructed by a selfinterest drive, a political choice to invest in its own interests and not the Cypriot interests.

Concluding, the Cypriot newspapers seemed to have struggled for the formation of the new political identity of Cyprus. Even though both ideological streams acknowledged the historical ties to Russia, the tension of the Eurogroup's decisions placed Cyprus (again) to identity construction processes. Historically the identity of Cyprus was negotiated mainly in terms of uniting with Greece or being a sovereign country while in the new political era of the EU, the main question that remained to be answered is if Cyprus was in position to choose its own allies and to construct its own sovereign identity.

Future studies may show in a long term how these have affected, both economically and geopolitically, given the gradual withdrawal of Russian interests from Cyprus and the growing Russian-Turkish relations.

\section{References:}

1. Altheide, D.L. (1997). The news media, the problem frame, and the production of fear. The sociological quarterly. 38(4). P. 647-668.

2. Bateson, G. (1972). Steps to an Ecology of Mind. New York: Balantine.

3. Bizer, G.Y., \& Krosnick, J. A. (2001). Exploring the structure of strength-related attitude features: The relation between attitude importance and attitude accessibility. Journal of Personality and Social Psychology. 81(4). P. 566-586.

4. Boeynaems, A., Burgers, C., Konijn, E. A., \& Steen, G.J. (2017). The effects of metaphorical framing on political persuasion: A systematic literature review. Metaphor and Symbol. 32(2). P. 118-134.

5. Chong, D., \& Druckman, J.N. (2007). Framing theory. Annu. Rev. Polit. Sci., 10. P. 103-126.

6. Coy, G.P. \& Woehrle, M.L. (1996): Constructing Identity and Oppositional Knowledge: The Framing Practices of Peace Movement Organizations During the Persian Gulf War, Sociological Spectrum. 16(3). P. 287-323.

7. Dettmer, M. \& Reiermann, C. (2012). Bailing Out Oligarchs.

8. URL: http://www.spiegel.de/international/europe/german-intelligence-report-warns-cyprus-not-combating-moneylaundering-a-865451.html

9. Dove, A.L., (2010). Framing Illegal Immigration at the U.S.-Mexican Border: Anti-Illegal Immigration Groups and the Importance of Place in Framing, pp. 199-237, in G.C. Coy (Eds.), Research in Social Movements, Conflicts and Change, Ohio: Emerald Group Publishing Limited.

10. Entman, R.M. (1993). Framing: Towards Clarification of a Fractured Paradigm. Journal of Communication, 43(4), 5158.

11. Fagley, N. S., \& Miller, P. M. (1997). Framing effects and arenas of choice: Your money or your life? Organizational behavior and human decision processes. 71(3), 355-373.

12. Franceschet, S. (2004). Explaining Social Movement Outcomes: Collective Action Frames and Strategic Choices in First- and Second-Wave Feminism in Chile, Comparative Political Studies, 37(5), 499-529.

13. Fitch, K. L. (1994). Criteria for evidence in qualitative research. Western Journal of Communication, 58, 32-38.

14. Fromm, E. (2001). The fear of freedom. Psychology Press.

15. Gamson, W. A. (1989). News as framing: Comments on Graber. American behavioral scientist, 33(2), $157-161$.

16. Goffman, E. (1974). Frame Analysis. New York: Harper and Row.

17. Jepperson, R. L., Wendt, A., \& Katzenstein, P. J. (1996). Norms, identity, and culture in national security. The culture of national security: Norms and identity in world politics, 33, 34.

18. Kihlstrom, J. F. (1987). The cognitive unconscious. Science, 237(4821), 1445-1452. 
19. Krippendorff, K. (2004). Reliability in content analysis. Human communication research, 30(3), 411-433.

20. Kühberger, A. (1998). The influence of framing on risky decisions: A meta-analysis. Organizational behavior and human decision processes, 75(1), 23-55.

21. Lecheler, S., deVreese, C. \& Slothuus, R. (2009). Issue Importance as a Moderator of Framing Effects. Communication Research, 36(3), 400-425.

22. Lerner, J. S., \& Keltner, D. (2001). Fear, anger, and risk. Journal of personality and social psychology, 81(1), 146.

23. Lillikas, G. (2014). The Image of Republic of Cyprus before and after the rejection of the Annan Plan. Pages $149-$ 164 at Samaras, Ath.N. (Ed.), Images of Nations; Strategic Communication, Soft Power and News Media, Athens: Kastaniotis Publications (in Greek).

24. Melakopides, C. (2016). Russia-Cyprus Relations: A Pragmatic Idealist Perspective. Springer.

25. Neuman, W. R., Just, M. R., \& Crigler, A. N. (1992). Common knowledge: News and the construction of political meaning. University of Chicago Press.

26. Pericleous, C. (2009). Cyprus Referendum: A Divided Island and the Challenge of the Annan Plan (Vol. 26). IB Tauris.

27. Price and Tewksbury cited in Schenck-Hamlin W.J., D.E. Procter and D.J. Rumsey, (2000). 'The Influences of Negative Advertising on Political Cynicism and Political Accountability", Human Communication 26(1), 53-74.

28. Ruggie, J. G. (1998). What makes the world hang together? Neo-utilitarianism and the social constructivist challenge. International organization, 52(4), 855-885.

29. Ruth, S. (1989). International Joint Enterprises in the Soviet Union. UCLA Pac. Basin LJ, 6, 121. URL: https://cloudfront. escholarship.org/dist/prd/content/qt5xd3n93m/qt5xd3n93m.pdf

30. Samaras, Ath.N. (2014). Images of Nations - Strategic Communication, Soft Power and News Media. Athens: Kastaniotis Publications (in Greek).

31. Samaras, Ath.N. \& Iordanidou, S., (2014). The Financial Crisis and the International Image of Germany. Pages 225 - 246 at Samaras, Ath.N. (Ed.), Images of Nations; Strategic Communication, Soft Power and News Media, Athens: Kastaniotis Publications (in Greek).

32. Sniderman, P. M., \& Theriault, S. M. (2004). The Structure of Political Argument and the Logic of Issue Framing, p. 133-165, in W.E. Saris \& P.M. Sniderman (Ed.) Studies in Public Opinion: Attitudes, Nonattitudes, Measurement Error, and Change, Oxfordshire: Princeton University Press.

33. Stavrinides, Z. (1975). The Cyprus conflict: national identity and statehood. Z. Stavrinides.

34. Takas, E., \& Samaras, A. (2016). Legitimation and de-legitimation processes of memorandum II in Greece: Facets of strategic framing in Greek parliamentary discourse. French Journal For Media Research, 5, 1-22.

35. Van Dijk, J. A. (2005). The deepening divide: Inequality in the information society. Sage Publications.

36. Venizelos, K., \& Ignatiou, M. (2002). The Secret Archives of Kissinger: A Decision for Division. Athens, Greece: Livanis Publishing.

37. Vrettos, S., \& Papagiannidis, A. (2013/2016). Society and Communication - Journalism. Open University of Cypprus. S. Iordanidou (ed.), Metamesonikties Ekdoseis (In Greek).

38. Wall Street Journal (2013). Money-Laundering Suspicion Stalls Europe's Latest Bailout (04.03.13). URL: https://www. wsj.com/articles/SB1000142412 7887323452204578292541738312974.

39. Yao, Q. (2007). China's official framing of religion and its influence on young Chinese students: A partial testing of the process model of framing in a special media environment. Asian Journal of Communication, 17(4), 416-432

40. Archive Sources.

41. Phileleftheros http://www.philenews.com/

42. Alithia http://www.alithia.com.cy/

43. Haravgi https://dialogos.com.cy/haravgi/

\section{ОЦЕНИВАНИЕ И СОЗДАНИЕ "ДРУГА" ВО ВРЕМЯ КРИЗИСА. ОБРАЗ РОССИИ В ГАЗЕТАХ КИПРА}

Основная иель настоящего исследования изучить и оценить диахронические отношения между Россией и Кипром, отметив их исторический контекст, и изучить воспринимаемый имидж России $b$ кипрской прессе $b$ критический период решений Еврогруппы в марте 2013 года.

В 1878 году Великобритания арендовала Кипр у Османской империи в обмен на обе- щание Великобритании помочь Туриии против России. В 1914 году Великобритания аннексировала остров, а Кипр стал британской колонией, потому что Османская империя вступила в Первую мировую войну на стороне цеентральных держав. Согласно Лозаннскому договору (1923 г.) османы отказались от всех своих требований b отношении Кипра, и новый 
статус побудил Великобританию объявить остров колонией Короны в 1925 г. (Stavrinides 1975, p.2). Это событие совпало с созданием Коммунистической партии Кипра (1926), что стало следствием глобального воздействия большевистского движения, натедшего своё выражение в Октябрьской революиии 1917 года. Эти события привели к культивированию внутри рабочего класса Кипра коммунистической идеологии, которая со временем привела к созданию Левого движения на Кипре. Помимо идеологических или религиозных объединений, основанных на общей доктрине, с 1960 года, после основания Республики Кипр, эти отнотения стали транснациональными $\mathrm{b}$ политическом и экономическом плане.

Кириакос Коловос,

$\mathrm{PhD}$ (доктор философии), Открытый университет Кипра, научный сотрудник

Ключевые слова:

Республика Кипр, Российская Федерация, отношения между Россией и Кипром
Института передовых медийных коммуни-

каций

Костас Венизелос,

$\mathrm{PhD}$ (доктор философии), приглашенный профессор, Европейский университет,

Кипр

Эммануил Такас,

$\mathrm{PhD}$ (доктор философии), Институт передовых медийных коммуникаций, Открытый университет Кипра, старший преподаватель политической и социальной психологии

София Иорданиду, доцент кафедры коммуникации и новой журналистики, Открытый университет Кипра, кафедра Института передовых передовых медийных коммуникаций.

\section{Keywords:}

the Republic of Cyprus, the Russian

Federation, relations between Russia and Cyprus 